\title{
Urban Health in Johannesburg: Migration, Exclusion and Inequality
}

\author{
Jo Vearey ${ }^{1}$
}

Published online: 23 March 2017

(C) The Author(s) 2017. This article is published with open access at Springerlink.com

Compared to their rural counterparts, cities are assumed to be spaces of improved access to livelihood opportunities and basic services - including healthcare, of better health outcomes, and of an extended life expectancy. At an aggregate level, this is often true but disaggregation of urban health indicators and outcomes within cities uncovers hidden intra-urban inequalities that clearly demonstrate that access to the urban benefit is unevenly distributed - in unjust, inequitable ways. Cities of the global southincluding Johannesburg - are associated with unplanned and unmanaged urban growth; poor urban governance (which is predominantly reactive rather than proactive); migration and mobility; and the resultant pressure on access to adequate services, including water, sanitation, housing, and healthcare. As a result, urban poor groups - including internal and cross-border migrants - who reside on the periphery of city welfare systems struggle to access the benefits of urban living. This leads to a large (majority) city population who fails to access the positive social determinants of urban health and, as a result, faces an urban health penalty (Freudenberg et al. 2005). Authorities responsible for cities in the global south are faced with increasingly complex, interlinked urban health challenges that affect different urban residents in different ways and require appropriate, localised, multi-sectoral, and multi-level responses (Vearey 2011).

Established in 1886 after the discovery of gold, the tented mining camp of Johannesburg was originally planned to last only as long as the initial "gold rush". But discovery of the largest gold reef in the world led to the development of the biggest gold mines globally and the associated in-migration of mining prospectors, mining companies, and - importantlymine labourers. From the onset, Johannesburg was planned as segregated on the basis of race and associated with unjust systems that simultaneously forced - and restricted - the movements of workers into and within the city. The result is that Johannesburg — or eGoli, "the city

Jo Vearey

jovearey@gmail.com

1 African Centre for Migration \& Society, University of the Witwatersrand, PO Box 76, Wits, Johannesburg 2050, South Africa 
of gold" - is a city built on migration and mining but its association with gold, wealth, and prosperity was, and still is - for the majority of its residents - misplaced. Johannesburg is now home to over four million residents; nearly half of whom were born in other provinces of South Africa (internal migrants) and around 13\% of whom are estimated to originate from other countries (City of Johannesburg 2013; StatsSA 2012). The legacy of apartheid urban policy and planning that prohibited black South Africans residing in cities without a pass generated the infamous Group Areas Acts that organised residential dwelling on the basis of race, and the equally unjust migrant labour system that continues to provide cheap labour in the mining sector has led to ongoing, persistent segregation within this historically divided city (Murray 2011). Today - as has been the case since the discovery of gold - the urban poor majority, themselves constituting a diverse population, and the wealthy elite minority live very different versions of the city. In just 131 years - thanks to migration and gold - the city has established itself both as the economic powerhouse of southern Africa and as (one of) the most unequal cities globally. Income inequality (measured through the Gini coefficient) continues to increase within South Africa, with the city of Johannesburg laying claim to the highest coefficient -0.67 in 2008 - indicating that the gap between the wealthy and the urban poor continues to grow. Large numbers of Johannesburg's residents live with "weak rights to the city" (Balbo and Marconi 2005, p. 13); poor, urban, non-migrant, and migrant groups (both internal and cross-border) experience challenges in realising their rights to access public healthcare, social services, employment, and secure tenure.

Located in a region associated with high levels of heterogeneous population movements, urban growth, and a large communicable disease burden-notably HIV and tuberculosis, the (in)famous city of Johannesburg provides a lens through which to explore migration, mobility, and health in southern Africa. Taking a broad definition of health - to incorporate issues of well-being, and not simply the absence of diseasethis special issue offers different ways of thinking about migration and health in contemporary urban spaces. With over $60 \%$ of the South African population residing in urban areas, and increases in the proportion of populations residing in towns and cities in the region, the need to understand and respond to urban health is increasingly important. In this issue, insights into how migration and mobility are mediating health within an African urban context are brought together. The papers bring the voices of different urban migrant groups to the fore and provide fresh perspectives on approaches for exploring how to research and respond to migration, mobility, and urban health in southern Africa. Advocating for mixed method and multi-disciplinary approaches, the papers provide important contributions to multi-disciplinary thinking around complex social issues.

The contributions explore how various structural determinants affect the health and well-being of migrants throughout their experiences of accessing and living in the city; policies, frameworks, and societal attitudes are central. Non-nationals, and other groups that experience stigma and discrimination, face multiple negative health consequences - including South African migrants who identify as transgender or intersex, as demonstrated through Husakouskaya's paper. Contributions from Oliveira, Schuler, and Walker highlight how choice of livelihood - in this case the sale of sex - can affect health and well-being through the structural and direct violence resulting from existing legal frameworks - including an increasingly restrictive Immigration Act and the criminalisation of sex work (Scheibe et al. 2016). Wilhelm-Solomon and Pedersen explore the relationship between health, sovereignty, and contemporary urban 
humanitarian reason in Johannesburg, whilst Jinnah's contribution explores the mental health experiences of Somali women refugees and asylum seekers, reminding us of the limitations of a biomedical approach to meeting the health and emotional well-being needs of diverse urban migrant populations. "Daily stressors"-stressful social and material conditions that are linked to social marginalisation, isolation, inadequate housing, and changes in family structure - affect well-being in the city (ACMS and CSVR 2011; Miller and Rasmussen 2010). A key stressor experienced by migrants in Johannesburg - as demonstrated in the contribution by Makandwa and Vearey-is access to healthcare, with the public health system itself recognised as a central determinant of health.

Whilst these papers highlight a need for migration-aware health system responses that can engage with and respond to the movement of people (Vearey 2016), they also remind us that responses to improve the health and well-being of urban poor migrant groups require a move beyond the health sector alone. South African local government has a "developmental mandate" that calls for government to work with citizens to develop sustainable interventions to address their social, economic, and material needs (The Republic of South Africa 1998). This obliges local government to move beyond its role as a provider of basic services, to one that develops and implements effective responses to more complex urban challenges. However, funding and support for such developmental activities from a national level is lacking, and there is currently only limited guidance for local government on how to enact this mandate. The papers presented here demonstrate the need to expand conceptions of health in contemporary urban spaces and emphasise that the (public) health system is just one of many determinants of health. Without addressing the causes of poor health, and recognising the factors that protect good health, attempts to improve the health of urban populations - particularly marginalised urban poor groups-will fail. Pro-poor policy and programme responses are urgently needed to improve the living and working conditions of diverse urban poor migrant groups in the city. Appropriate, dedicated funding from the national treasury and shifts in the ways in which local government is structured - that would allow for the development and implementation of more flexible, proactive, innovative, multi-level, and intersectoral responses to complex urban health challenges - are required. The contributions in this issue emphasise the need for local government to work with multiple stakeholders - including migrants themselves - to unpack the complexity of lived experiences in the city and apply its developmental mandate to leverage intersectoral and multi-level action to urgently address urban health and migration in Johannesburg.

Open Access This article is distributed under the terms of the Creative Commons Attribution 4.0 International License (http://creativecommons.org/licenses/by/4.0/), which permits unrestricted use, distribution, and reproduction in any medium, provided you give appropriate credit to the original author(s) and the source, provide a link to the Creative Commons license, and indicate if changes were made.

\section{References}

ACMS, \& CSVR. (2011). Exploring the psychosocial \& health rights of forced migrants in Johannesburg. The impact of "daily stressors" on the emotional wellbeing of forced migrants.

Balbo, M., \& Marconi, G. (2005). Governing international migration in the city of the south, (38). 
City of Johannesburg. (2013). 2012/16 Integrated development plan: 2013/14 Review. Johannesburg: City of Johannesburg.

Freudenberg, N., Galea, S., \& Vlahov, D. (2005). Beyond urban penalty and urban sprawl: back to living conditions as the focus of urban health, 30(1), 1-11.

Miller, K., \& Rasmussen, A. (2010). War exposure, daily stressors, and mental health in conflict and postconflict settings: bridging the divide between trauma-focused and psychosocial frameworks. Social Science and Medicine, 70(1), 7-16.

Murray, M. (2011). City of extremes. The spatial politics of Johannesburg. Johannesburg: Wits University Press.

Scheibe, A., Richter, M., \& Vearey, J. (2016). Sex work and South Africa's health system: addressing the needs of the underserved. South African Health Review, 165-178.

Stats SA. (2012). Census 2011: census in brief. Pretoria: StatsSA.

The Republic of South Africa. (1998). The white paper on local government. Pretoria: The Department of Constitutional Development.

Vearey, J. (2011). Challenging urban health: towards an improved local government response to migration, informal settlements, and HIV in Johannesburg, South Africa. Global Health Action, 4(0). http://www. globalhealthaction.net/index.php/gha/article/view/5898. Accessed 17 December 2015

Vearey, J. (2016). Mobility, migration and generalised HIV epidemics: a focus on sub-Saharan Africa. In F. Thomas (Ed.), Handbook on migration and health. Cheltenham: Edward Elgar Publishing. 